\title{
Adorning the Body, Asserting Status: Prestige-Goods and Social Distinction at Ancient Chadic Chiefdom of Houlouf (Northern Cameroon)
}

\author{
Augustin Ferdinand Charles Holl \\ Department of Anthropology and Ethnology, School of Sociology and Anthropology, Africa Research Center, Belt and Road Research \\ Institute, Xiamen University, Xiamen, Fujian, P. R. China
}

Email address:

gaochang@xmu.edu.cn

\section{To cite this article:}

Augustin Ferdinand Charles Holl. Adorning the Body, Asserting Status: Prestige-Goods and Social Distinction at Ancient Chadic Chiefdom of Houlouf (Northern Cameroon). International Journal of Archaeology. Vol. 8, No. 2, 2020, pp. 22-31. doi: 10.11648/j.ija.20200802.12

Received: November 13, 2020; Accepted: November 23, 2020; Published: December 4, 2020

\begin{abstract}
Copper and alloyed copper artefacts, carnelian and glass beads have been recovered in archaeological excavations since the middle of the $20^{\text {th }}$ century in the Chadian plain in northern Cameroon, northeastern Nigeria and southwestern Chad Republic. The initial research projects conducted by Marcel Griaule and Jean-Paul Lebeuf resulted in the "creation" of the Sao Civilization, characterized by a relatively high level of art craftmanship. They made impressive large pottery vessels, terracotta figurines, iron objects, and copper and alloyed copper artefacts, called "Sao Bronzes". These artefacts were generally analysed from their supposed artistic characteristics; production techniques - the lost wax technique - were addressed but no metal production features were ever recorded in the first decades of research on northernmost Cameroon mounds. The Houlouf archaeological project conducted from 1981 to 1991 allowed for a better understanding of the production and use of the copper/alloyed copper artefacts and other prestige goods recovered from archaeological contexts. They range widely in nature, forms, and shape. There are ordinary personal adornment items - finger-rings, arm-rings, and ankle rings, necklaces, waistbeads - to very specialized cavalry - leg-guards - and archery - arm-bands -, including exceptional figurines. This contribution brings to light the context of use and socio-political implications of these prestige artefacts and outlines their meaning in the developing Central Sudan long-distance trade networks.
\end{abstract}

Keywords: Alloyed Copper, Copper, Carnelian, Glass Beads, Personal Adornment, Prestige Good, Grave Goods, Houlouf, Cameroon, Chadian Plain, Central Africa

\section{Introduction}

After leading the Mission Dakar-Djibouti (1931-1933) and before launching his long-term Dogon country anthropology project. Marcel Griaule [1] focused on the Chad basin and conducted fieldwork on the mound sites of the Chad plain. Fascinated by folk stories, he published "Les Sao Legendaires" in 1943, features a bygone civilization of giants, manufacturing large So-pots, terracotta figurines, and mastering copper and iron metallurgy. He literally created the "Sao Civilization" and initiated systematic archaeological fieldwork with his then partner Jean-Paul Lebeuf, to documents this vanished culture [2-4]. Jean-Paul Lebeuf and Annie Masson-Detourbet Lebeuf kept on with the tradition [5-9]. They conducted combined archaeological and ethnographic research on kotokos polities $[10,11]$ and retired in the early 1980 s.

It was shown that the term Soo or Sao was a Kanuri word used to refer to the mound-dwellers, speakers of Chadic languages and ancestors of present-day Kotoko. The expression "Sao Civilization" that gained currency during the Colonial Period and was even part elementary school history textbook was an artificial construct. Ancient Chadic polities is probably a more accurate label. The Houlouf archaeological project launched in 1981 initiated a shift from a single-site approach to a regional archaeology perspectives with the focus on the formation and evolution of a Chadic polity [12-17]. 


\section{Adorning the Body, Asserting Status: Theoretical Perspectives}

Objects are polysemic, consistently and systematically multivalent. Whatever the case, none has intrinsic "natural" value. Value, in this perspective, is the product of human cognitive ability to generate symbols and assign meaning. Objects values are therefore social currencies. However, the concept of "value" is not as simple as intuitively suggested above [18-21]. Marx suggested in his 1844 manuscripts that "it is use that determines a thing's value and that fashion determines use" [19]. Use-value is accordingly determined by demand. Air is an essential life-supporting element, indispensable to any breathing creature; it has no price-tag, no exchange-value.

"The classical economist Adam Smith asked why water, which is essential to life, is normally very cheap while inessential diamonds are very expensive. The resolution depended on distinguishing between value in exchange and value in use. While the total contribution to economic welfare of water, or its use value, is very high, it is so abundant relative to other, perhaps less essential resources, that it exchanges in markets for only small quantities of the other resources." [21].

Things with higher utility like air and water tend to have the lowest value and those with low utility like diamond, gold, jewellery, etc.. tend to have higher value. Use value and exchange value are incommensurable but they are nonetheless "inseparable dialectical aspects of the social unit the commodity" [19]. Things or objects, subsumed under the category of material culture, crafted and used by humans, can be differentiated by raw materials, labour invested in their procurement and transformation, their distribution and use.

There is an unstable system of use and display of material culture. It is a process in which material capital is translated into higher valued symbolic capital [22]. Exotic and scarce materials as well as personal adornments objects tend to be relied upon to display and assert social statuses [23, 24]. A ruler is symbolized by a crown, a warrior by a sword. The working of such a dynamic system thus requires either local procurement of critical raw materials and/or access via long distance exchange networks, skilled labour to process the raw material and manufacture prestige-goods items, and finally, their distribution, acquisition, use, display, and final disposal, in this case in burial contexts. This paper examines how copper and alloyed copper objects were used in social distinction strategies set in place by the elite members of the Houlouf, an ancient Chadic Polity in the Northern Cameroon portion of the Chadian plain between 1000 and $1800 \mathrm{CE}$. [Common Era].

\section{Methodology}

\subsection{The Houlouf Archaeological Project}

The Houlouf Archaeological project was initiated in 1980. Archaeological fieldwork organized in 10 field seasons was conducted from 1981 to 1991. Data processing, laboratory analyses and writing too some ten years to be completed, with the complete monograph published in 2002 [15]. The delineated study area, situated at $11^{\circ} 40^{\prime}-12^{\circ} 10^{\prime}$ latitude North and $14^{\circ} 50^{\prime}-15^{\circ} 15^{\prime}$ longitude East, measures 500 square kilometers (figure 1), delimited in the east by the meandering course of the Logone River. The area situated in northern most Cameroon is located in the Chadian plain. It is a low-lying landscape with arbustive savanna and grassland in the annually flooded depressions. 20 archaeological sites of varying size and shape were mapped and 14 excavated. The recorded occupation sequence of the Houlouf region that started around 1900 BCE (Before Common Era) following the receding of Lake Chad is approximately 4000 years long. It is divided into 5 main phases with varying number of sites in each.

The initial Deguesse phase (ca. 1900 BCE - 0 CE (Common Era)) is comprised of two sites, Deguesse and Krenak, both mobile pastoral groups occupations on the receding Lake Chad islands. It is followed by the Krenak phase ()$-500 \mathrm{CE})$ that witnessed the formation of sedentary village communities. It is made of four equidistant settlements, Ble, Deguesse, Houlouf and Krenak, located along the lake's shore in a deltaic contexts. The number of established settlements shifted from 4 to 8 during the Mishiskwa phase $(500-1000 \mathrm{CE})$, with the addition of Hamei, Krenak-Sao, Madaf and Mishiskwa. Settlement growth is sustained during the Ble Phase $(1000$ - $1400 \mathrm{CE})$ with this time 10 sites arranged into two competing peerpolities: the Houlouf one in the northwest with Deguesse, Hamei, Madaf and Houlouf, the Ble-5 - Mounds complex in the southeast, and Mishiskwa as an outlier. During the Houlouf phase (1400-1800 CE) that witnessed a dry spell, the number of sites dropped to 7 , with a significant shift westward. Houlouf became the main center of the dominant polity, with a virtual monopoly on exotic prestige goods, including alloyed copper artefacts, carnelian and glass beads [12-17].

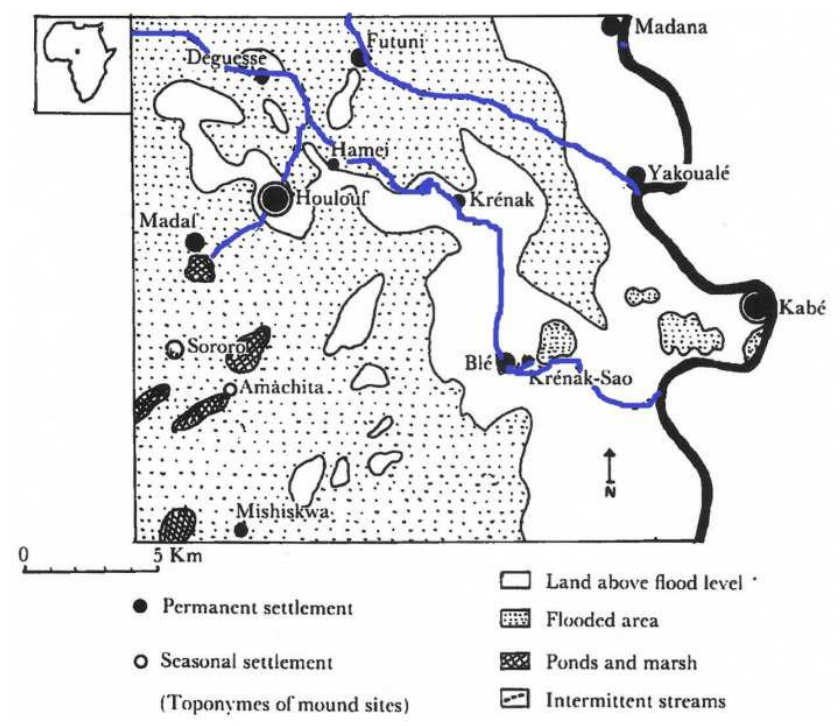

Figure 1. Archaeological sites from the Houlouf Region. 


\subsection{The Archaeological Record: Houlouf Copper/Alloyed Copper Artefacts}

One hundred copper/alloyed copper artefacts were excavated from the earthen-walled central site of Houlouf. Tbe earliest specimens, dated to $500 \mathrm{CE}$ at the beginning of Mishiskwa phase and collected in Houlouf occupation II at 3.20-3.40 m below the surface, consist of 4 buttons, likely part of an unpreserved garment. The discovery of a crucible at Mishiskwa along with evidence of copper slag fragments recorded in the Houlouf archaeological sequence, at 1.60-1.80 $\mathrm{m}$ dated to $1165-1190 \mathrm{CE}$ and $0.30-0.60 \mathrm{~m}$ dated to $1500-1600$ $\mathrm{CE}$, point to the local production of at least some of the alloyed copper objects. Two techniques were generally in use. The lost-wax technique was used for the production of dense artefacts such as arm-rings, rings, torque and spurs. Hot and cold hammering combined with welding and bending was used for the manufacture of leg-guards and arm-bands

Most of the recorded copper/alloyed copper artefacts were collected from burials. They were used for personal adornment, and prestige items signalling achieved social status. The Items of personal adornment are distributed into four categories: arm-rings, rings, torque, and buttons and garment-tokens. Status objects, all related to war and horsemanship, include leg-guards, arm-bands, and spurs.

Table 1. Distribution of copper/alloyed copper items of personal adornment.

\begin{tabular}{|c|c|c|c|c|c|c|c|}
\hline \multirow{2}{*}{ Context } & \multicolumn{3}{|c|}{ Personal adornment } & \multicolumn{3}{|c|}{ War and horsemanship } & \multirow{2}{*}{ Total } \\
\hline & Arm-ring & Ring & Other & Leg-guard & Arm-band & Spur & \\
\hline \multicolumn{8}{|c|}{ Houlouf Phase (1400 - $1800 \mathrm{CE})$, cemetery } \\
\hline Burial 11 & 4 & 3 & 2 & 2 & 1 & - & 12 \\
\hline Burial 12 & 2 & 1 & - & - & - & 2 & 5 \\
\hline Burial 13 & 7 & - & - & 2 & - & - & 9 \\
\hline Burial 16 & 1 & 2 & - & - & - & - & 3 \\
\hline Burial 17 & - & - & - & - & - & 2 & 2 \\
\hline Burial 20 & - & - & - & - & 1 & - & 1 \\
\hline Burial 21 & 1 & 1 & - & - & - & 2 & 4 \\
\hline Burial 26 & - & 1 & - & - & - & - & 1 \\
\hline Burial 27 & - & - & - & 2 & - & - & 2 \\
\hline Burial 30 & 3 & 4 & - & - & - & - & 7 \\
\hline Burial 31 & - & 1 & - & - & - & - & 1 \\
\hline Burial 32 & 4 & 2 & - & - & - & - & 6 \\
\hline Burial 34 & - & 1 & - & 2 & - & - & 3 \\
\hline Burial 36 & 1 & 3 & - & - & - & - & 4 \\
\hline Burial 43 & 1 & - & - & - & - & - & 1 \\
\hline Burial 50 & 7 & - & - & 2 & - & - & 9 \\
\hline Total & 30 & 20 & 2 & 10 & 2 & 6 & 70 \\
\hline \multicolumn{8}{|c|}{ Ble Phase (1000 -1400 CE) } \\
\hline Square C3 & 2 & - & - & - & - & - & 2 \\
\hline Burial 58 & 1 & - & 1 & - & - & - & 2 \\
\hline Burial 60 & - & 2 & - & - & - & - & 2 \\
\hline Burial 68 & - & - & - & 2 & - & - & 2 \\
\hline Burial 70 & 1 & - & - & - & - & - & 1 \\
\hline Burial 74 & 1 & - & - & - & - & - & 1 \\
\hline Burial 7513 & - & - & - & & 2 & 15 & \\
\hline Burial 78 & 1 & - & - & - & - & - & 1 \\
\hline Burial 81 & 1 & - & - & 2 & - & - & 3 \\
\hline Burial 83 & 1 & - & - & - & - & - & 1 \\
\hline Total & 21 & 2 & 1 & 4 & - & 2 & 30 \\
\hline \multicolumn{8}{|c|}{ Mishiskwa phase $(500$ - $1000 \mathrm{CE})$} \\
\hline Courtyard & - & - & 4 & - & - & - & 4 \\
\hline Burial 80 & - & 1 & - & - & - & - & 1 \\
\hline Total & - & 1 & 4 & - & - & 5 & \\
\hline
\end{tabular}




\subsection{Structures and Patterning of the Recorded Material Culture}

The sample of copper/alloyed copper artifacts collected from the Central site of Houlouf amounts to 105 specimens (Table 1). 5 specimens were collected from the Mishiskwa phase (ca. $500-1000 \mathrm{CE}$ ) deposit, shifted to 30 in Ble phase (1000-1400 CE) levels, and finally peaked at 70 in the Houlouf phase (1400 - $1800 \mathrm{CE})$.
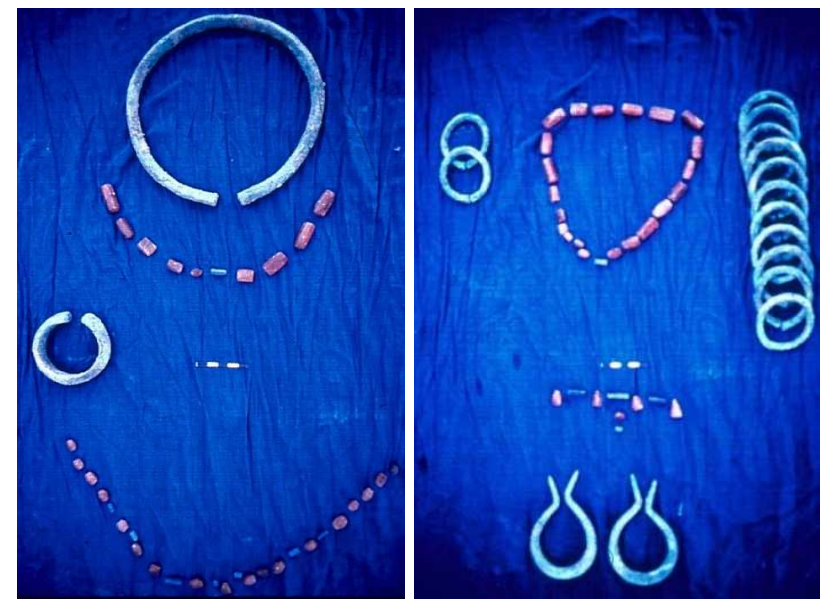

Figure 2. Carnelian beads and associated copper artefacts from Ble Phase (1000-1400 CE) female and male burials.
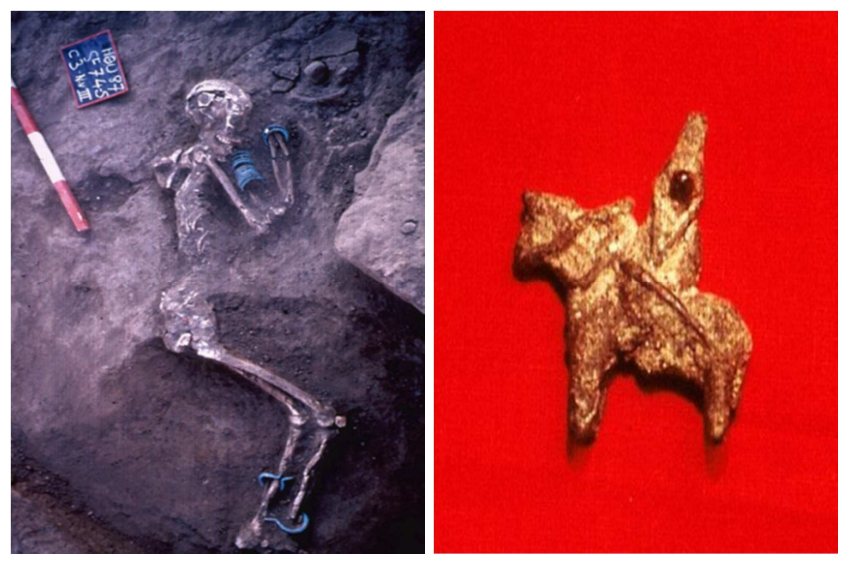

Figure 3. Ble Phase (1000-1400 CE) horse-ridder burial and a horse-ridder copper figurine.

Ble phase Copper/alloyed copper artifacts were collected from 9 burials but their distribution is strongly skewed in favor of burials 75 and 81 which contained 18 items out of 30. Burials. Spurs are clearly use for the handling of horses and leg-guards protect the legs and ankles of horse-ridders against ennemies swords in cavalry engagements. Accordingly, the items of horsemanship point to the emergence and existence of a corps of elite warriors at the Houlouf earthen-walled city during the Ble phase (figure 3).

Social differentiation and trends toward stronger social ranking were amplifyed during the Houlouf phase (14001800 CE). Houlouf, protected by a strong earthen rampart became the un-rivalled primate center of the polity of the same name. It witnessed the installation of a restricted access elite cemetery (figures 4 and 5), indicated by a dense cluster of large vessels used as grave-markers, arranged around a central monument (figure 5), with tightly regulated burial protocol (figure 7).

The highly choreographed mortuary program mobilized a relatively large number of copper/alloyed copper artefacts, carnelian beads and other exotic raw materials. The cemetery is divided in four burial-clusters [12-15] with 4 to 8 burials each, arranged around the central effigy-jar. A detailed analysis of the main aspects of the Houlouf phase cemetery will allow for a better grasp of the social use of copper/alloyed copper artefacts and other exotic goods.

\section{Results}

\subsection{The Houlouf Phase Cemetery (1500-1600 CE)}

The Houlouf phase cemetery, dated to 1500-1600 CE, is relatively densely packed with 25 burials in less than 40 square meters in the north half of the Houlouf excavation probe (figure 6). The graves are indicated by 1 to 3 superimposed large clay vessels (figure 4), without contact with the skeletons, explicitly used as "burial-markers". All the deceased are buried in sitting position, facing southwest as the effigy-jar central monument (figure 5), with feet in a large pot (figure 7). The Cemetery is organized in four burialclusters located in the SE, SW, NE and NW (figure 8).

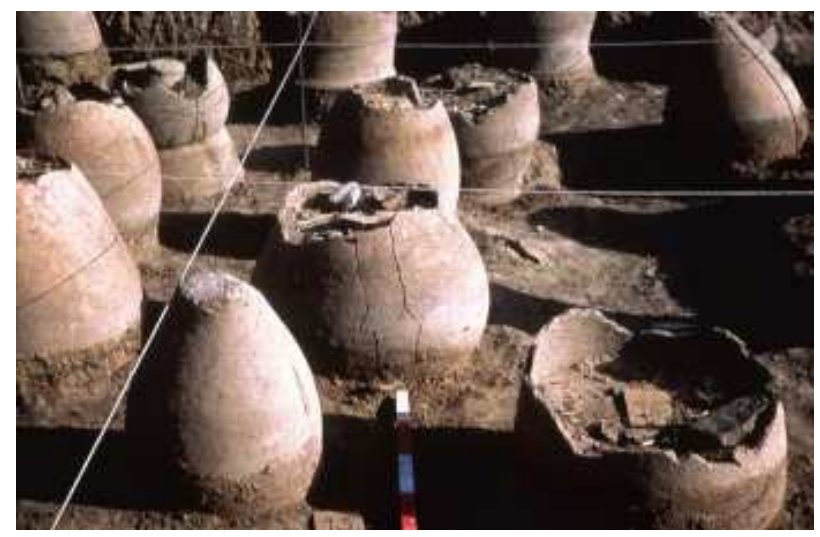

Figure 4. Partial view of Houlouf phase elite cemetery.

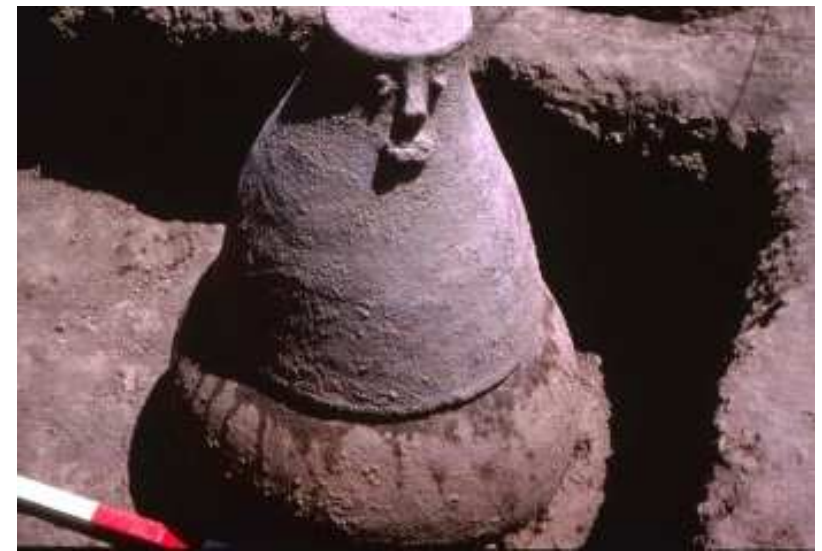

Figure 5. The Effigy-Jar central monument of Houlouf elite cemetery, facing southwest. 
The SE cluster includes 8 burials. The burial facilities are made of 1 to 3 large vessels grave-markers and 1 to 2 pots for feet with one exception (burial 20). Burial inclusions, de facto grave-goods consist of 1 to 12 copper/alloyed copper artefacts per burial with one exception (Burial 22) (table 2), 5 to 174 carnelian beads, 1 to 3 coarse stone artefacts, and finally, 2 cases of terracotta figurines (table 2).

The SW cluster is made of 7 burials, with 1 to 2 large vessels tomb-markers and $1-3$ Pots. 1 to 3 copper/alloyed copper artefacts were recorded from 4 burials, 1 to 58 carnelian beads, 1 glass bead, 2 cases of terracotta figurines, as well as 1 to 3 coarse stone artefacts (table 2).

There are six burials in the NW cluster, with single large vessel tomb-marker and 1 pot for feet in 4 occurrences. 1 to 7 copper/alloyed copper artefacts were collected from 4 burials, along with 3 to 42 carnelian beads, 1 terracotta figurine, and 3 coarse stone artefacts (table 2).

Finally, the NE cluster, the smallest, consists of 4 burials, each with one large vessel grave-marker and 1 feet-pot. 3 to 7 copper/alloyed copper artefacts as well as 8 to 134 carnelian beads, and 1 to 2 coarse stone artefacts have been recorded in 2 of the burials (table 2).

The differential distribution of grave-goods points to the existence of outstanding individuals cumulating distinct symbols of power and prestige. Beside personal adornment artefacts represented by copper arm-rings and rings, carnelian, glass, and clay beads (table 2), some peculiar objets such as arm-bands, leg-guards, and spurs point to prestigious warriors and horsemen status. Arm-bands found in Burial 11 and 20 are used to protect the wrist from the return vibration of the bow string. The are accordingly archers' equipment. They are particularly cumbersome, weighing 0.650 and $0.750 \mathrm{~kg}$, made of two bent and welded copper/alloyed copper sheets. Leg-guards, also made with bent copper/alloyed copper sheets were used to protect horseridders legs and ankles from ennemys' sword hits. They are found in 5 burials (Burial 11, 13, 27, 34, and 50) and weigh 0.640 to $0.310 \mathrm{~kg}$. And finally spurs, designed for horseridding, are found in burial 12, 17, and 21 .

Table 2. Distribution of burial facilities and grave-goods.

\begin{tabular}{|c|c|c|c|c|c|c|}
\hline Feature & Tomb & Feet & Copper & Carnelian & Clay & Coarse \\
\hline Number & marker & pot & artefacts & beads & beads & stone \\
\hline \multicolumn{7}{|l|}{ SE cluster } \\
\hline Burial 11 & 3 & 1 & 12 & 115 & - & - \\
\hline Burial 12 & 3 & 1 & 5 & 42 & - & - \\
\hline Burial 13 & 2 & 1 & 9 & 174 & 1 & - \\
\hline Burial 20 & 1 & - & 1 & 11 & - & 3 \\
\hline Burial 22 & 1 & 1 & - & 7 & 1 & 3 \\
\hline Burial 43 & 2 & 2 & 1 & 5 & - & 1 \\
\hline Burial 50 & 1 & 1 & 9 & 126 & - & - \\
\hline Total & 14 & 8 & 41 & 616 & 2 & 8 \\
\hline \multicolumn{7}{|l|}{ SW cluster } \\
\hline Burial 14 & 2 & - & - & 4 & - & 1 \\
\hline Burial 17 & 2 & 1 & 2 & 58 & 1 & 3 \\
\hline Burial 18 & 2 & 1 & - & 18 & - & - \\
\hline Burial 26 & 1 & 1 & 1 & 15 & 1 & - \\
\hline Burial 27 & 1 & 1 & 2 & 10 & - & 2 \\
\hline Burial 56 & 1 & 1 & - & 1 & - & - \\
\hline Total & 11 & 8 & 8 & 106 & 2 & 6 \\
\hline \multicolumn{7}{|l|}{ NW cluster } \\
\hline Burial 29 & 1 & - & - & - & - & 1 \\
\hline Burial 30 & 1 & 1 & 7 & 5 & - & 1 \\
\hline Burial 31 & 1 & 1 & 1 & - & - & - \\
\hline Burial 35 & 1 & 1 & - & 3 & - & 1 \\
\hline Burial 36 & 1 & 1 & 4 & 42 & 1 & - \\
\hline Burial 37 & 1 & - & - & - & - & - \\
\hline Total & 6 & 4 & 12 & 50 & 1 & 3 \\
\hline Burial 24 & 1 & 1 & - & - & - & - \\
\hline Burial 32 & 1 & 1 & 7 & 134 & - & - \\
\hline Burial 34 & 1 & 1 & 3 & 8 & - & 2 \\
\hline Total & 4 & 4 & 10 & 142 & - & 2 \\
\hline
\end{tabular}




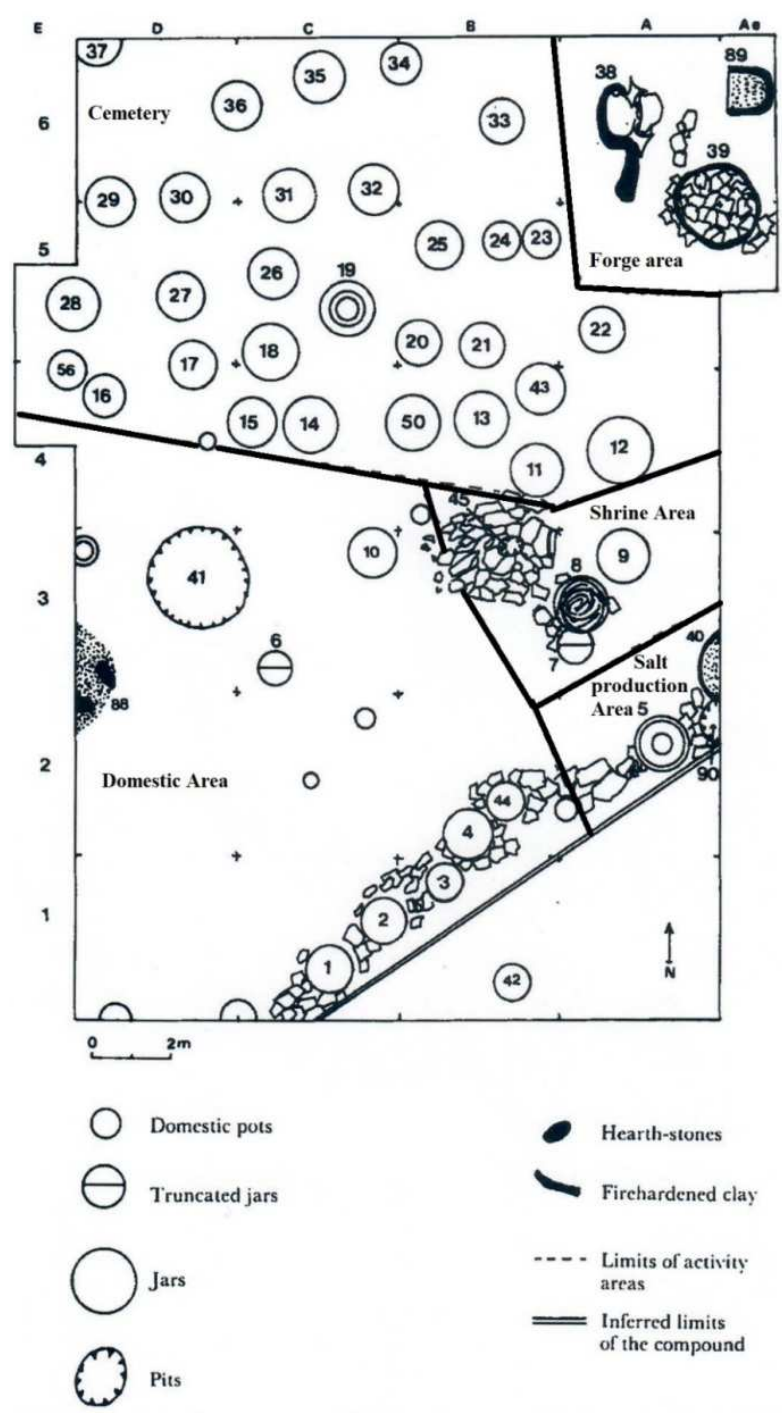

Figure 6. Houlouf Phase level VII with a restricted access cemetery in the northern half.

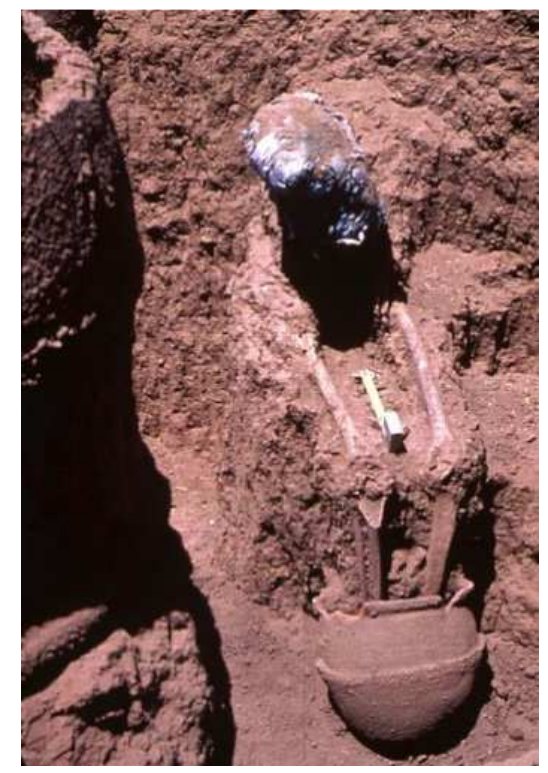

Figure 7. The deceased are buried in sitting position, facing southwest, with feet in a large pot.

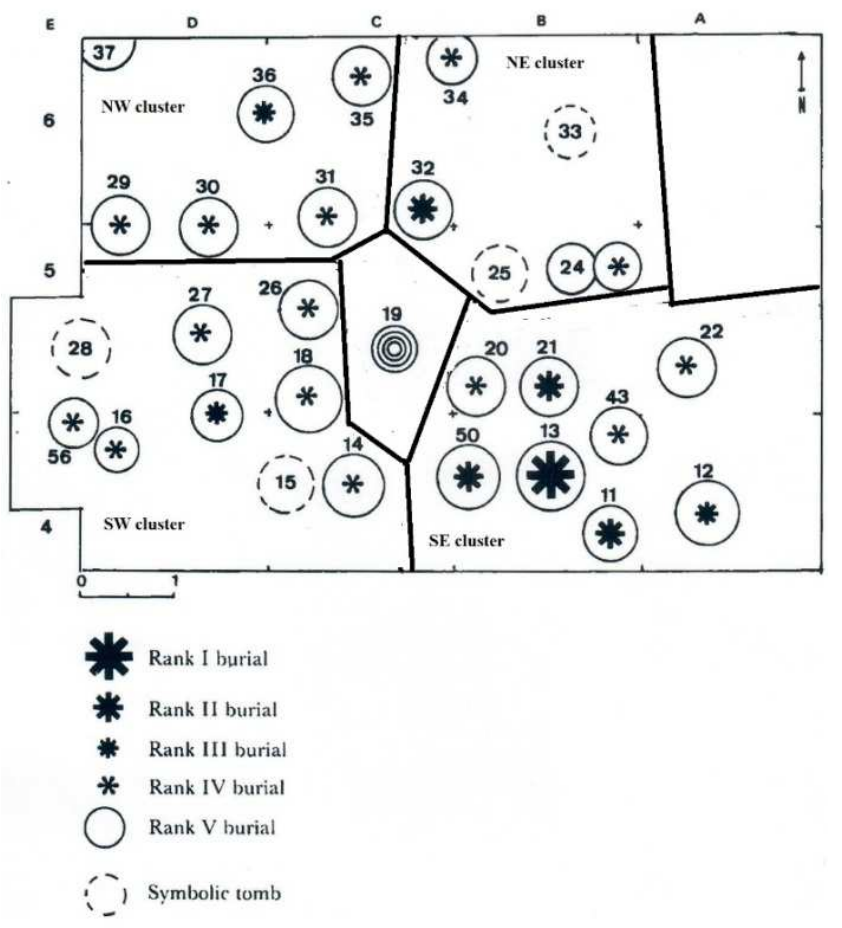

Figure 8. Organization of the Houlouf phase cemetery with burials ranking.

High-ranking individuals, from Rank I and II are found in 2 of the 4 identified clusters, with the highest concentration in the SE cluster (figure 8). The latter includes Burial 13, the top-ranked individual with 174 carnelian beads, 2 leg-guards, and 7 arm-rings; Rank II Burial 11, 21, and 50, with respectively 115 carnelian beads, 4 arm-rings, 2 rings, 2 legguards, 1 arm-band, and 2 copper/alloyed copper garment tokens for the first, 136 carnelian beads, 1 arm-ring, 1 ring, and 1 coarse rock for the second; and finally, 126 carnelian beads, 7 arm-rings, and 2 leg-guards for the third.

In contrast to the distribution of carnelian beads, the distribution of copper/alloyed copper artefacts is limited to 16 burials out of 29 . They are predominantly made of personal adornment items, 32 arm-rings, 18 rings, and 2 garments tokens found in 14 burials. The Warriors and horseridders status symbols are restricted to 9 individuals: Rank I individual 13, Rank II individuals 11, 21, 32, and 50, Rank III individuals 12 and 17, and finally Rank IV individuals 20, 27, and 34 .

\subsection{Metallographic Analyses}

Eighteen copper/alloyed copper artefacts from the Houlouf phase deposit were submitted to advanced metallographic analyses (table 3). All the analyzed specimens are basically ternary to quaternary alloys with copper $(\mathrm{Cu})$ proportions ranging a maximum of $89.45 \%$ in an arm-band from burial 11 to a minimum of $61.20 \%$ in an arm-ring from burial 32 (Table 3). With very few exceptions, each artefact presents a unique combination of metal components, suggesting that each order was unique, the melted metal obtained from ingots or worn out objects from different origins.

Burial 11 arm-band has the highest proportion of copper 
$(\mathrm{Cu})$, with the other 3 key components ranging from $4.50 \%$ for tin $(\mathrm{Sn}), 2.65 \%$ for lead $(\mathrm{Pb})$ and $2.00 \%$ for zinc $(\mathrm{Zn})$.
Burial 20 specimen has higher proportion of lead, $7.20 \%(\mathrm{~Pb})$ and zinc, $8.00 \%(\mathrm{Zn})$.

Table 3. Metallographic composition of Houlouf phase copper/alloyed copper artefacts.

\begin{tabular}{|c|c|c|c|c|c|c|c|c|c|c|c|}
\hline Context & $\mathbf{C u}$ & Sn & $\mathbf{P b}$ & As & $\mathbf{S b}$ & Ag & $\mathbf{N i}$ & $\mathbf{B i}$ & $\mathrm{Fe}$ & Zn & Mn \\
\hline \multicolumn{12}{|l|}{ Arm-bands } \\
\hline Burial 11 & 89.45 & 4.50 & 2.65 & 0.60 & 0.50 & 0.08 & 0.20 & 0.025 & 0.001 & 2.00 & - \\
\hline Burial 20 & 75.95 & 2.00 & 7.20 & 1.20 & 0.60 & 0.08 & 0.04 & 0.01 & 2.00 & 8.00 & - \\
\hline \multicolumn{12}{|l|}{ Leg-guards } \\
\hline Burial 12 & 78.10 & 6.85 & 8.15 & 0.40 & 0.60 & 0.15 & 0.15 & 0.02 & 0.10 & 5.50 & - \\
\hline Burial 13 & 79.55 & 4.20 & 6.40 & 0.10 & 0.30 & 0.06 & 0.03 & 0.007 & 0.50 & 8.80 & - \\
\hline Burial 13 & 78.50 & 6.55 & 7.80 & 0.30 & 0.40 & 0.07 & 0.10 & 0.03 & 0.20 & $6.00-$ & \\
\hline Burial 50 & 72.50 & 6.80 & 14.50 & 0.25 & 0.25 & 0.10 & 0.05 & 0.005 & 0.05 & 5.50 & $\operatorname{tr}$ \\
\hline Burial 50 & 74.75 & 1.90 & 14.05 & 1.00 & 1.20 & 0.10 & 0.40 & 0.015 & 0.10 & 6.50 & - \\
\hline \multicolumn{12}{|l|}{ Arm-rings } \\
\hline Burial 32 & 73.00 & 2.80 & 4.10 & 1.50 & 1.00 & 0.30 & 0.08 & 0.03 & 1.50 & 10.00 & $\operatorname{tr}$ \\
\hline Burial 32 & 61.20 & 0.50 & 12.80 & 0.06 & 0.05 & 0.04 & 0.01 & $\operatorname{tr}$ & 0.15 & 25.00 & $\operatorname{tr}$ \\
\hline Burial 32 & 74.80 & 3.80 & 10.80 & 0.25 & 0.15 & 0.05 & 0.02 & 0.003 & 0.10 & 10.00 & $\operatorname{tr}$ \\
\hline Burial 32 & 88.00 & 7.00 & 2.00 & 0.20 & 0.40 & 0.08 & 0.008 & 0.002 & 0.25 & 2.00 & 0.005 \\
\hline \multicolumn{12}{|l|}{ Rings } \\
\hline Burial 21 & 79.40 & 7.30 & 1.25 & 0.50 & 0.80 & 0.15 & 0.05 & 0.02 & 0.25 & 10.00 & $\operatorname{tr}$ \\
\hline Burial 31 & 61.20 & 4.40 & 13.20 & 0.25 & 0.25 & 0.06 & 0.15 & 0.008 & 0.40 & 20.00 & $\operatorname{tr}$ \\
\hline Burial 36 & 87.50 & 1.00 & 4.20 & 0.80 & 0.20 & 0.08 & 0.025 & 0.005 & 1.00 & 5.00 & 0.003 \\
\hline $\begin{array}{l}\text { Burial } 36 \\
\text { Spurs }\end{array}$ & 85.50 & 1.00 & 1.50 & 0.60 & 0.35 & 0.05 & 0.02 & 0.005 & 0.80 & 10.00 & 0.003 \\
\hline Burial 17 & 73.40 & 0.50 & 4.50 & 2.00 & 0.30 & 0.08 & 0.03 & 0.002 & 4.00 & 15.00 & 0.003 \\
\hline
\end{tabular}

Key: $\mathrm{Cu}=$ copper; $\mathrm{Sn}=$ tin $; \mathrm{Pb}=$ lead; $\mathrm{As}=$ arsenic $; \mathrm{Sb}=$ antimony; $\mathrm{Ag}=$ silver; $\mathrm{Ni}=$ nickel; $\mathrm{Bi}=$ bismuth $; \mathrm{Fe}=$ iron; $\mathrm{Zn}=$ zinc $; \mathrm{Mn}=$ manganese

The leg-guards can be split into two groups. One made of 4 specimens from Burial 12, 13 and 16 have $\mathrm{Cu}$ proportions ranging from 79.55 to $78.10 \%$, Sn from 3.00 to $6.85 \%, \mathrm{~Pb}$ form 5.60 to $8.15 \%$ and finally, $\mathrm{Zn}$ from 5.50 to $8.80 \%$ (table 3). The other with two leg-guards from Burial 50 have lower $\mathrm{Cu}$ proportions, respectively 72.50 and $74.75 \%, 1.90$ to $6.80 \%$ $\mathrm{Sn}, 14.05$ to $14.50 \% \mathrm{~Pb}$ and 5.50 to $6.50 \% \mathrm{Zn}$. Each of the arm-rings presents a unique combination of metal components. $\mathrm{Cu}$ proportions range from 61.20 to $88.00 \%$, Sn from 0.50 to $7.00 \%, \mathrm{~Pb}$ form 2.00 to $12.80 \%$, and finally, $\mathrm{Zn}$ from 2.00 to $25.00 \%$. The situation is identical for the recorded rings, belonging to burial 21 and 36 . The set from burial 21 has 61.20 to $79.40 \% \mathrm{Cu}, 4.40$ to $7.30 \% \mathrm{Sn}, 1.25$ to $13.20 \% \mathrm{~Pb}$, and 10.00 to $20.00 \% \mathrm{Zn}$. Burial 36 specimens have 85.50 to $87.50 \% \mathrm{Cu}$, $1.00 \% \mathrm{Sn}, 1.50$ to $4.20 \% \mathrm{~Pb}$ and Finally, 5.00 to $10.00 \mathrm{Zn}$. And the single specimen of spur has $73.40 \% \mathrm{Cu}, 15.00 \% \mathrm{Zn}$ $4.50 \% \mathrm{~Pb}$ and $0.50 \% \mathrm{Sn}$.

Copper and alloyed copper raw material, along with other exotic objects like carnelian and glass beads, were accessed through long-distance trade networks that connected different parts of the continent in the last two millennia.

\subsection{Long Distance Trade Connections and Exchange Dynamics}

Provenience studies of African archaeological material culture are still very limited [25-27]. No significant research has been carried on the sources of a large spectrum of raw materials that was traded through African past long-distance exchange networks [23]. Sutton (1991 [29]) revived Arkell's [30] idea of Cambay (India) as the source of carnelian beads found in Africa. According to him, carnelian beads produced at Cambay in India were shipped through Red Sea harbours, to Egypt and from there transited through the Nile valley, Nubia and the Chad basin to reach Igbo Ukwu region in southeastern Nigeria $[31,32]$ in the $10^{\text {th }}$ Century CE. Sutton [29] acknowledges that his suggestion is highly speculative and untestable. The scanty archaeological work conducted in the eastern part of the Chad basin [33] and Central Darfur further east [34] does not provide additional evidence and supporting data.

Evidence attesting for the production of carnelian beads have been recorded in Mali, at a few thousands kilometers west of the Chad basin. These workshops are located in the Tilemsi valley, from the Adrar-n-Ifoghas in the north to the Niger river bend in the South [35]. A calcedony outcrop named as "La station de la calcedoine" was found at about 50 kilometers north of Kidal in the Adrar-n-Ifoghas. The site measures approximately 1 hectare in surface extent.

"Presque toutes les variétés (de calcédoines) sont présentes: agate, onyx, chrysoprase, jaspe, cornaline, toutes roches vivement colorées et tellement brillantes que les deux Sonray qui nous accompagnaient se mirent à pousser des cris de joie, persuadés que nous venions de découvrir une mine de pierres précieuses. Toute l'industrie est lisse, brillante comme vernie, et il apparaît que la technique de chauffe préalable à la taille ait été systématiquement utilisée» [35].

[Almost all kinds of calcedony are represented: agate, onyx, chrysoprase, jasper, carnelian, all very colourful and shining rocks, so that both Sonray guides screamed of excitement, convinced that that have just discovered a mine of precious stones. All the manufactures artefacts are smooth and shining as if varnished. It appears that heating prior to 
shaping was systematically used" [35]

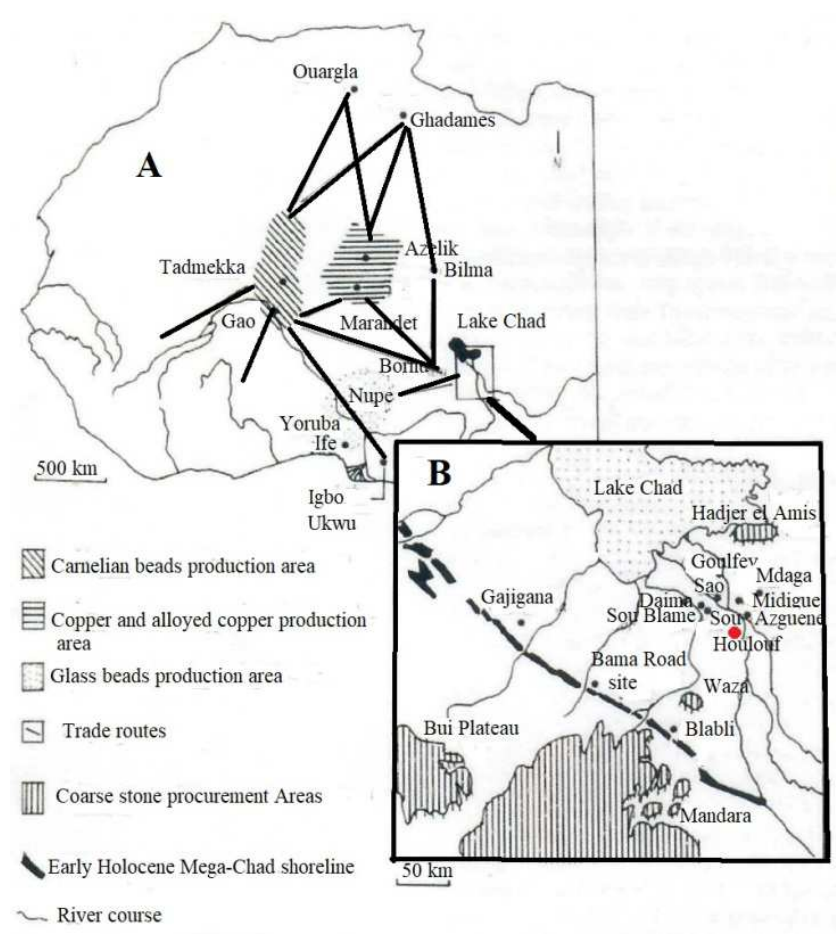

Figure 9. Map of some West African long-distance exchange network during the last 2 millennia.

Many other workshops were recorded at Asselar, Eblebit, Smar Smarren, Nilkit Mich II, Ilouk, Gadaoui, Lagreich Neo 1, In Arabou, Aoukert and Gao-Hydrocarbure on the shore of the river Niger. The highest concentration of complete carnelian beads was recorded at the latest site. It is in the latter site. At each of the recorded workshop, the concentration of carnelian beads production waste is very high, suggesting a specialized craft provisioning groups far above the needs of the involved domestic units. Surface sites are difficult to date without careful excavations. However, carnelian beads were found in burial mounds of the Inland Niger Delta dated to $700-1100 \mathrm{CE}[36,37]$ and in other archaeological sites such as Goa-hydrocarbures [37], Igbo Ukwu [31, 32], in In Gall Tegidda-n-Tesemt burial mounds [38], and at Tin Nak I in Telataye region in the Tilemsi valley [35].

The location of carnelian beads production workshops, set between Tadmekka and Ghadames (figure 9A), as well as their relatively high value in contemporary societies are described by Al Bakri who lived in Al Andalus in 1100 -1200 $\mathrm{CE}$ as follows:

"Another road from Tadmekka to Ghadamis: you go from Tadmekka for six days over the country inhabited by the Saghmara and then through the waterless waste for four days before attaining water, and then through another waterless région also four days. In this second waste is a mine of stone called tasi-n-nasamt, which resembles agate (aqiq). Occasionally you may find in one stone varions colors such as red, yellow, or white. Sometimes, though very rarely, a large, fine stone is found. When such a stone is brought to the people of Ghana, they value it extravagantly and pay a high priée for it. They consider it to be more splendid than any other precious object. This stone is polished and pierced by means of another stone called ti-n-tuwas in the same way as rubies are polisbed and pierced with emery. Iron would make no impression on it at ail without the ti-n-tuwas. The place where this stone lies can only be located precisely by slaughtering a camel and sprinkling its blood over the mine. The stones thus appear and may be picked up.» [40]

Carnelian beads were accordingly manufactured in the Tilemsi valley and the Adrar-n-Ifoghas from the first millennium $\mathrm{CE}$ on. They were involved in the cycles of exchange Saharan pastoralists, berbers and Tuareg, and sedentary populations from the Niger river. Goods were dispatched either through the Niger river traffic or on land through caravans. The Niger river systems operated with dug-out flotillas that could reach, as far as Igbo Ukwu region in southeastern Nigeria. Merchants caravans, sponsored by Arab, Berber, Tuareg, Hawsa, Diulas, Kanuri, etc. connected the rest of West Africa to North Africa, the In Gall Tegidda-nTesemt to the Hawsa city-states and the Bornu kingdom, reaching the mound sites from the Chad basin (figure 9A and B). Accelerated social differentiation had boosted the demand for scarce and exotic materials and prestige goods and facilitated the deployment of long-distance trade networks

As was the case for carnelian beads, copper and alloyed copper, as ingots or artefacts, were parts of the goods exchanged in the long-distance trade networks that crisscrossed Central and West Africa. There are abundant evidence for the smelting and production of copper artefacts in the mound sites from the Chad plain $[23,7,9,12,13,15])$. There are two possible sources of the copper and alloyed copper found in the mound sites of the Chad plain. One is the Bauchi plateau in Nigeria, a few hundred kilometers southwest of the Chad plain and the other is the In Gall Tegidda-nTesemt region in Niger, also a few hundred kilometers away but in the Northwest (figure 9).

Data on Bauchi plateau copper metallurgy are ambiguous and uncertain. The exploitation of tin is however well documented. There is better documentation on the In Gall Tegidda-n-Tesemt region metallurgy with the important production centers of Azelik, Marandet, and other smaller stations dated between 500 and 1800 CE [41, 42]. Archaeological research points to particularly intensive copper production at Marandet between 800 and $1000 \mathrm{CE}$ and Azelik and surrounding lands from 1100 to $1600 \mathrm{CE}$. Ibn Battuta provide some information on the circulation of copper and copper objects made at Takadda (Azelik) in 1355:

".... the copper is transported from here to the city of Kùbar in the land of the Infidels and to Zaghay and the land of Burnii, which is at a distance of forty days from Takadda... From this country they bring handsome slave girls ijawari) and young men slaves (fityan) and cloth dyed with saffron (Jasad)" [40].

Copper from Azelik was shipped in different directions, including the kingdom of Bornu [Burnii] where it was 
exchanged for young male and female slaves and famous dyed tuniques [tobbes] made by ancestral kotoko inhabiting the Chadian plain mound sites. Kotoko merchants caravans connected Bornu markets places to different cities of the Chadian plain. The raw material and manufactured objects obtained by those who could afford them were forwarded to blacksmiths workshops to be made into arm-band, leg-guard, spur, arm-ring, ring, or garments tokens to be used in daily life activities.

\section{Conclusion}

Copper and alloyed copper raw material and artefacts were parts of high-value prestige items that played important roles in the emergence and development of ancient African longdistance trade networks. These commodities were used by local elites to assert and display their social statuses. The earthen-walled 15.5 ha center of Houlouf achieved regional primacy in 1400 - 1800 CE Houlouf phase, and monopolized access to exotic prestige goods. Relying on raw material obtained very likely from neighbouring Bornu kingdom markets, local elites commissioned a diversified range of copper/alloyed copper objects from local blacksmiths workshops. These insignia, part of the elite members social persona and glued to their statuses ended up in their final resting places, in their burials.

\section{Acknowledgements}

The "Houlouf Archaeological and Ethnoarchaeological Project" (1981-1991) from which data discussed in this paper were obtained was funded by grants from the National Center for Scientific Research (CNRS, France), the Ministry of Cooperation (France), the Ministry of Foreign Affairs (France) and the National Geographic Society (Grant \# 3715-87).

\section{References}

[1] Griaule, M. 1943. Les Sao Legendaires. Paris; Gallimard.

[2] Griaule, M. and J. P. Lebeuf 1948. Fouilles dans la région du Tchad. Journal de la Société des Africanistes 18 (1): 1-116.

[3] Griaule, M. and J. P. Lebeuf 1950. Fouilles dans la région du Tchad. Journal de la Société des Africanistes 20 (1): 1-152.

[4] Griaule, M. and J. P. Lebeuf 1951. Fouilles dans la région du Tchad. Journal de la Société des Africanistes 21 (1): 1-95.

[5] Lebeuf, J. P. 1969. Carte archéologique des abords du lac Tchad. Paris: Ed. du CNRS.

[6] Lebeuf, J. P. 1981. Supplément à la carte archéologique des abords du lac Tchad. Paris: Ed. du CNRS.

[7] Lebeuf, J. P., and A. M. D Lebeuf 1950. La civilisation du Tchad. Paris; Payot.

[8] Lebeuf, J. P. and A. M. D Lebeuf 1977. Les Arts Sao. Paris: Ed. du Chêne.
[9] Lebeuf, J. P.,. and A. M. D Lebeuf, F. Treinen-Claustre and J. Courtin 1980. Le Gisement Sao de Mdaga (Tchad). Paris: Soc. d'Ethnographie.

[10] Lebeuf, A. M. D. 1969 Les Principautes Kotoko: Essai sur le caractere sacre de l'autorite. Paris; Editions du CNRS.

[11] Lebeuf, A. M. D. 1992. Le site de Sou: étude d'une aire d'activité domestique. In: J. M. Essomba (ed), L'archéologie au Cameroun. Paris: Khartala, p. 79-89.

[12] Holl, A. 1988. Houlouf I: Archéologie des Sociétés Protohistoriques du Nord Cameroun, Cambridge Monographs in African Archaeology, British Archaeological Reports, International Series, Oxford.

[13] Holl, A. F. C. 1994. The Cemetery of Houlouf, Northern Cameroon (AD 1500-1600): Fragments of a Past Social System. The African Archaeological Review 12: 133-170.

[14] Holl, A. 1995. Réseaux d'échanges préhistoriques dans la Plaine Tchadienne. SAHARA 7: 17-28.

[15] Holl, A. F. C. 2002. The Land of Houlouf: Genesis of a Chadic Polity (1900 B. C.-1800 A. D.). Memoirs of the Museum of Anthropology series, No. 35, Ann Arbor.

[16] Holl, A. F. C. 2006. Pathways to Complexity: The Rise and Demise of a Chadic Polity. GEFAME: Journal of African studies 3 (1) -57 pages. Online.

[17] Holl, A. F. C. 2015. Site Location, Exchange and Production: The Emergence of Houlouf Polity in the Chadian Plain. Studies in African Past 12: 202-217.

[18] Appadurai, A., editor 1988. The Social Life of Things: Commodities in Cultural Perspective. Cambridge; Cambridge University Press.

[19] Keen, S., 1993, Use-value, Exchange value, and the demise of Marx labor theory of Value. Journal of the History of Economic Thought 15: 107-121.

[20] Marx, K. 1959. Economic and Philosophic Manuscripts of 1844. Moscow; Progress Publishers.

[21] Stern, D. I., 1999. Use value, exchange value, and Resource Scarcity. Energy Policy 27: 469-476.

[22] Bourdieu, P., 1979. La Distinction: Critique Sociale du Jugement. Paris; Editions de Minuit.

[23] Berger, A. A. 2014. What Objects Mean: An Introduction to Material Culture. London; Routledge.

[24] Insoll, T. 2015. Material Explorations in African Archaeology. Oxford; Oxford University Press.

[25] Lagamma, A. editor 2020. Sahel: Art and Empires on the Shores of the Sahara. New York/New Haven/London; The Metropolitan Museum of Art and Yale University Press.

[26] Robertshaw, P., S. Magnavita, M. Wood, E. B. Melchiorre, R. S. Popelka-Filcoff and M. D. Glascock, 2009. Glass beads from Kissi (Burkina Faso): Chemical Analysis and Archaeological Interpretation. Journal of African Archaeology 2: $105-118$.

[27] Sterry, M. and D. J. Mattingly, editors 2020. Urbanisation and State formation in the Ancient Sahara and Beyond. Cambridge; Cambridge University Press. 
[28] Connah G. 1981. Three thousand years in Africa. Cambridge: Cambridge University Press.

[29] Sutton, J. E. G. 1991. The international factor at Igbo Ukwu. The African Archaeological Review 9: 145-160.

[30] Arkell, A. J. 1936 Cambay and the Bead Trade, Antiquity 10 (35): 292-305.

[31] Shaw, T. 1970. Igbo Ukwu: an account of archaeological discoveries in eastern Nigeria. London: Faber.

[32] Shaw, T. 1977. Unearthing Igbo Ukwu. Ibadan: Oxford University Press.

[33] Treinen-Claustre, F. 1982. Sahara et Sahel à l'Age du fer: Borkou, Tchad. Paris, Société des Africanistes.

[34] Mohammed, M. 1986 Archaeology of Central Darfur. Cambridge Monographs in African Archaeology; Oxford: BAR.

[35] Gaussen J. and M. Gaussen 1988. Le Tilemsi préhistorique et ses abords: Sahara et Sahel malien. Paris, Ed. du CNRS.

[36] Desplagnes, L. 1907 Le plateau central nigérien: une mission archéologique et ethnographique au Soudan français. Paris: Larose.
[37] Fontes P. B., A. Person ET J. F. Saliege, 1991. Prospection des sites archéologiques de la région des lacs et du Delta intérieur du Niger (1980). In: M. Raimbault et K. Sanogo (eds), Recherches archéologiques au Mali. Paris: Karthala ACCT, p. 27-61.

[38] Paris, F. 1984. La région d'In Gall-Tegidda-n-Tesemt (Niger) III: les sépultures du Néolithique final à l'Islam. Niamey: Inst. de Recherches en Sciences Humaines.

[39] Duhard, J. P. and J. Gaussen 1990. La station sépulcrale de Tin-Nak I (Age du fer malien). Bulletin de la Société d'Anthropologie du Sud-Ouest, 25 (2): 85-103.

[40] Levtzion N. and J. F. P. Hopkins, editors 1981 Corpus of early Arabie sources for West African history. Cambridge: Cambridge University Press.

[41] Grebenart, D. 1985. La Région d'In Gall-Tegidda-n-Tesemt (Niger) II: Le Néolithique final et les débuts de la Métallurgie. Niamey: Institut des Recherches en Sciences Humaines.

[42] Bernus, S. and P. Cressier 1991. La Région d'In Gall-Tegidda$n$-Tesemt (Niger) IV: Azelik-Takadda et l'implantation sédentaire. Niamey: Institut de Recherches en Sciences Humaines. 